\title{
A Bundeswehr SVFuA harcászati rádiókommunikációs rendszer beszerzése
}

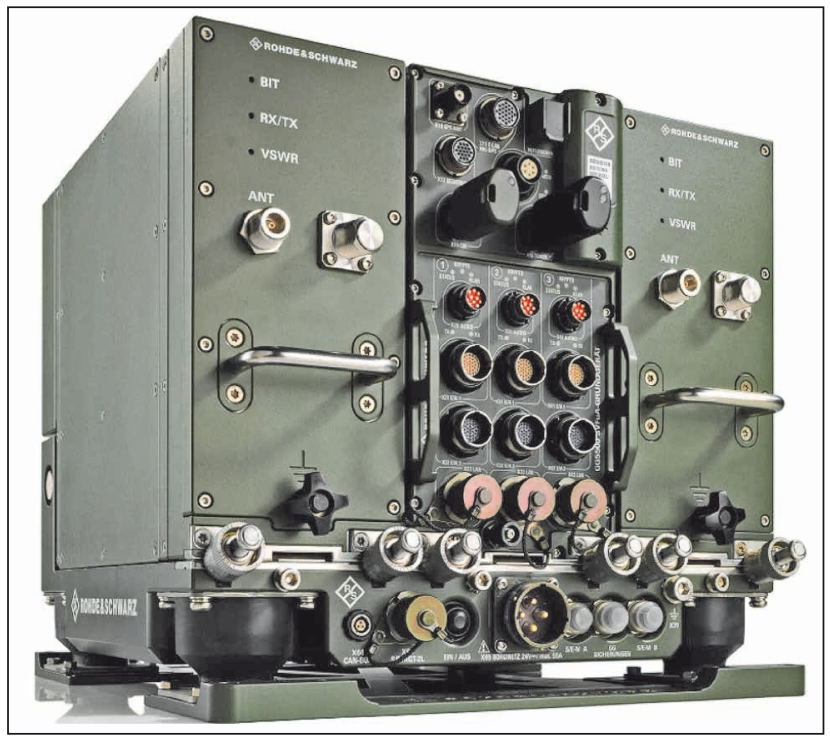

1. ábra. A Rohde \& Schwarz cég SVFuA szoftvervezérlésü harcászati rádiórendszerének bázisállomása

$\Lambda$ müncheni Rohde \& Schwarz elektronikai konszern 2017. június végén megbízást kapott a Német Szövetségi Védelmi Minisztériumtól (BMVg) egyelőre 50 darab SPz Puma és GTK Boxer páncélozott szállító harcjármú parancsnoki változatának ún. SVFuA (Streitkräftegemeinsame Verbundfähige Funkgeräte-Ausstattung) összhaderőnemi, szoftvervezérlésű harcászati rádiókkal történő felszerelésére. Az SVFuA projekt a német fegyveres erők mobilkommunikációs gerinchálózatának digitalizálását elöirányzó (MoTaKo) program egyik preferált fejlesztése.

Több éves közös fejlesztés után a Bundeswehr közbeszerzési hivatala (BAAINBw) szerződést kötött a Rohde \& Schwarz elektronikai cégcsoporttal a német fegyveres erők jövőbeni közös, interoperábilis harcászati rádiórendszerének, az SVFuA-nak a beszerzésére. A müncheni székhelyü Rohde \& Schwarz cég a rádiótávközlés, a védett vezeték nélküli kommunikáció és az információbiztonság (divatosabb szóval kibervédelem) területén a világ élvonalába tartozó piacvezető gyártó, NATO beszállító. A szerződés pénzügyi volumene mintegy 80,9 millió euró, amelyhez

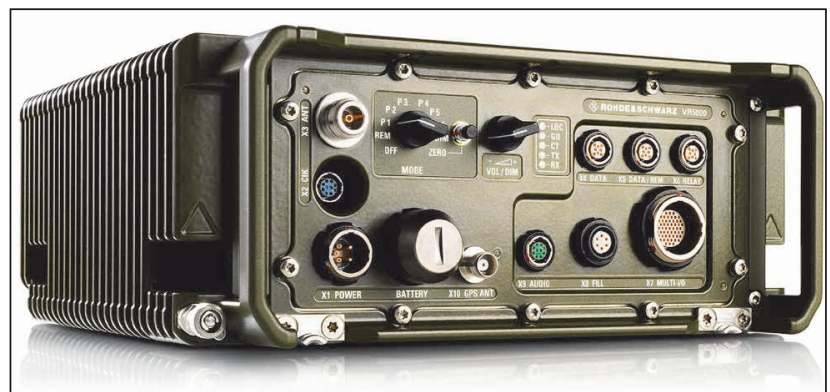

2. ábra. A Rohde \& Schwarz cég jármúvekben való használatra optimalizált VHF/UHF - sávú $50 \mathrm{~W}$ adóteljesítményű, szoftvervezérelt harcászati rádiója

10,6 millió euró értékben kiegészítő szerződések társulnak. A szerződés egy további opciót tartalmaz 475 darab SVFuA beszerzéséről. A rádiórendszer első sorozatának legyártása és leszállítása 2020-ig esedékes.

Az SVFuA program következőgenerációs mobil rádió adó-vevők fejlesztését foglalja magába, amelyek hálózati csomópontokként, valamint letölthető keskeny- és szélessávú hullámformákkal bíró terminálokként múködhetnek. A jövőben ezek a rádiórendszerek alkotják majd a Bundeswehr mobilkommunikációs gerinchálózatát. Mint ismert, a rádiók digitalizációja felé a mikroprocesszor és a nagy bonyolultságú integrált áramkörökkel felépített alkalmazásspecifikus moduláris egységek technológiájának alkalmazása volt az első lépés. Az egyre nagyobb teljesítményú digitális jelfeldolgozó processzorok, analóg-digitális átalakítók és szűrők a hagyományos rádiókészülékeknél technológiailag lehetővé tették az analóg jelfeldolgozás digitálissá változtatását. Az analóg-digitális jelátalakítás mindinkább a végerősítő (RF részek), valamint az antenna irányába tolódott el. Az átviendő információ (beszédhang vagy adat) és az antennáról kisugárzandó, vagy az arról nyert elektromágneses hullám között algoritmikus összefüggésként jött létre a hullámforma fogalma. A szoftver-vezérelt rádiók hardvere és szoftvere tervezésében - ide értve a nemzeti kriptográfiai modulok integrációját is - az úgynevezett SCA (Software Communications Architecture) nemzetközi szoftverkommunikációs szabvány segített. (Az SCA tulajdonképpen egy nyitott szoftveres keretrendszer, ahol a programozható hardverekbe hullámformák tölthetők be,

ABSTRACT: In the future, the Bundeswehr mobile communications backbone network will be based on the software defined tactical radio system of the Rohde \& Schwarz electronics group in Munich. The SVFuA provides a selforganizing mobile radio network with extremely safe wide-band voice and data communications, which is an important prerequisite for network-centric command of the Bundeswehr forces.

KEY WORDS: Bundeswehr, SVFuA software defined tactical radio, Rohde \& Schwarz electronics group
KULCSSZAVAK: Bundeswehr, SVFuA szoftvervezérlésű harcászati rádió Rohde \& Schwarz elektronikai konszern 


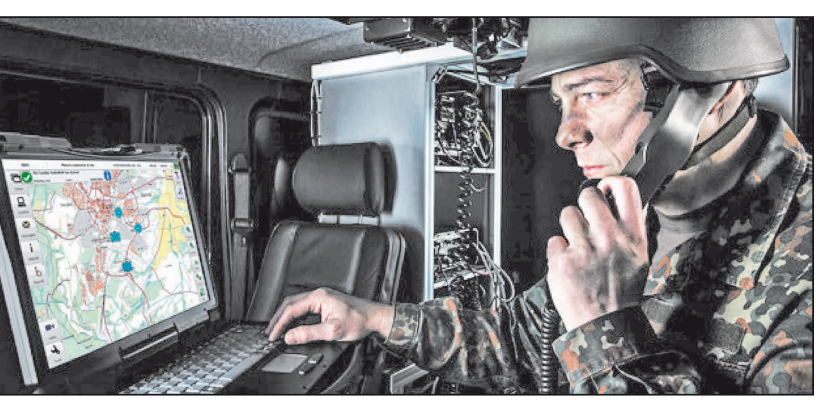

3. ábra. Az SVFuA szoftvervezérelt harcászati rádiók szélessávú, nagy adatsebességű kommunikációra képesek NATO titkos minősítési szintig

szoftveres alkalmazások futtathatók, és lehetőség van hálózatkialakításra.)

Az SVFuA-t többfunkciós rendszerként tervezték. (A többfunkciós jelző az 1,5-600 MHz sávban üzemelni képes hardver-kialakítás sajátja, figyelembe véve a katonai rádiórendszerek frekvenciaigényét.) A rendszerhez $\mathrm{HF}(1,5-30 \mathrm{MHz}$ ) és VHF/UHF (30-600 MHz) frekvenciatartományú adóvevő modulok, valamint egy szélessávú modul $(600 \mathrm{MHz}-3 \mathrm{GHz})$, továbbá SVFuA kiegészítő elemek tartoznak. Bázisállomás biztosítja a digitális jelfeldolgozást és az interfészeket a lehetséges végberendezésekhez, a belső kommunikációs rendszerekhez, a vezetési és fegyverirányítási rendszerekhez, a vezetési információs rendszerekhez és a router funkciókhoz, valamint a beszéd- és adattitkosításhoz. A bázisállomással optikai interfészen keresztül összekötött adóvevő modulok alakítják át a digitális jeleket a végerősítőnek és továbbítják az antennára.

Az SVFuA programmal a NATO csapatrádiókra vonatkozó hullámforma-standardet, a Bundeswehrben rendszeresített SEM típusú rádiókészülékek hullámformáit, a MAHRS/TIGER hullámformát, valamint egy hálózatképes hullámformát egyaránt adaptáltak. A hullámformák SVFuAra való letöltésével lehetővé vált egy új hullámforma (harmadik fél által létrehozott hullámformákat is beleértve) kifejlesztése. Tekintettel arra, hogy az SVFuA rendszert az SCA szabvány szerint fejlesztették, lehetőség van a jelenlegi és a jövőbeli, nemzeti és nemzetközi hullámformák rádiórendszerbe történő letöltésére, amennyiben ezek a hullámformák az SCA szabvány követelményeinek megfelelnek.

\section{4. ábra. Parancsnoki GTK Boxer belső tere munkahelyekkel}

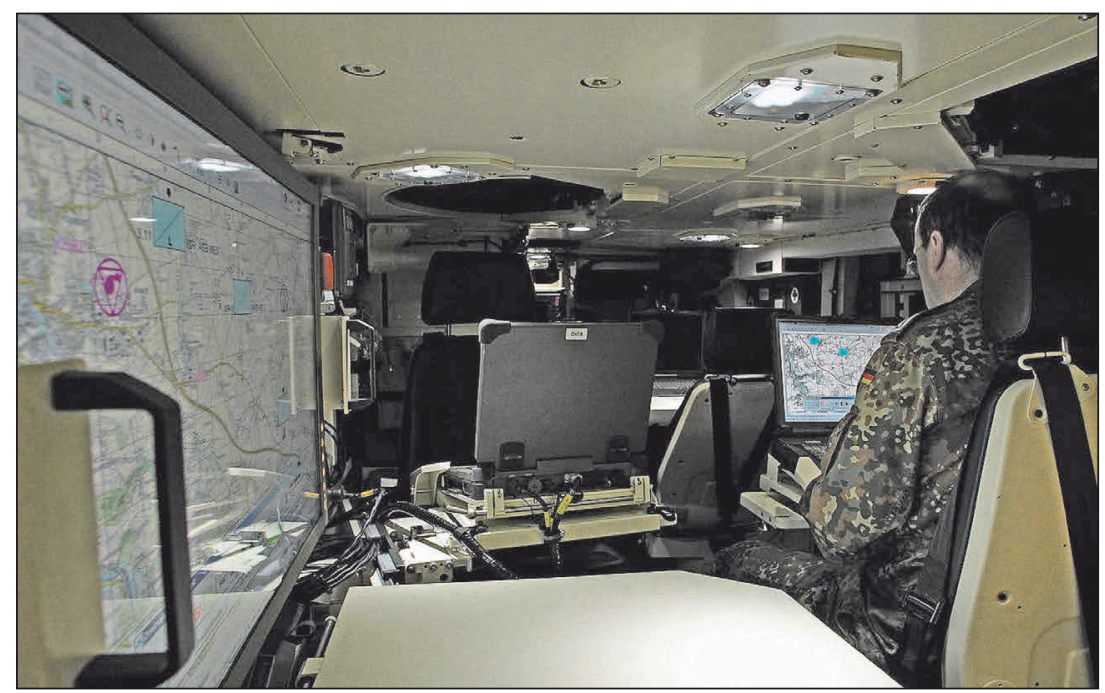

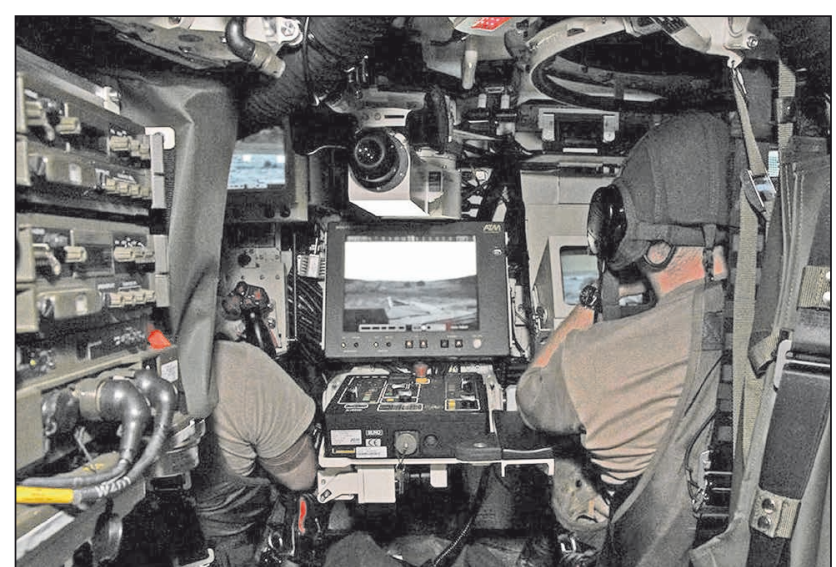

5. ábra. A parancsnoki SPz Puma munkahelyei $360^{\circ}$-os kilátást biztosítanak

A próbák során bizonyítást nyertek az egyidejű beszéd-, adat- és képátviteli képességek, valamint prototípusosan az egyidejü védett beszéd- és adatátvitel is. Az SVFuA rendszer, az alkalmazott átviteli módtól függetlenül képes titkos, illetve NATO titkos biztonsági szintű rádiókommunikációra. (Az erre vonatkozó tanúsítványt a Szövetségi Információbiztonsági Hivatal 2016 februárban kiadta.). Az SVFuA hálózatképes hullámformák letöltésével ad-hoc hálózatkialakítási képességgel bővíthető. A szoftverből letölthető hullámformák alkalmazásával nagysebességü, szélessávú adatátvitelre képes. Az integrált routing technológia (útvonalválasztás) és az internetprotokoll révén illeszkedik a mobil rádió-kommunikációs gerinchálózatához, a működő rádiórendszerekhez és információ-továbbítási módszerekhez.

Az SVFuA önszervező mobil rádióhálózatot biztosít rendkívül biztonságos, szélessávú hang- és adatkommunikációval, ami fontos előfeltétele a Bundeswehr csapatai hálózatközpontú vezetésének. A szoftverrádió-koncepció megfelel a német fegyveres erők növekvő interoperabilitási igényeinek. Szoftver által definiált hullámformák segítségével az SVFuA úgy konfigurálható, hogy megfeleljen a mindenkori feladat követelményeinek.

Az SVFuA fejlesztésére különféle technológiai kihívások voltak hatással, amelyek miatt az induláskor jóváhagyott időkeret nem volt tartható. A tervet különféle paramétereknek, mechanikai, hő- és elektromos faktoroknak is meg kellett feleltetni. Az SVFuA fejlesztése 2016 májusában zárult. A mobil védett vezeték nélküli kommunikációs képességkülönbségek ezzel megszűnnek, a Bundeswehr egy méretezhető, újra-konfigurálható, és ezzel jövőképes rádiós platformot kap. Az előírt követelmények, különösen a különböző platformok más hálózatokkal, más forgatókönyvek szerinti összekapcsolása, a hullámforma-applikációk igény- és helyzetmegfelelő alkalmazásával a rádióberendezések változtatása nélkül teljesíthetők. Így az SVFuA rádiók típus-sokfélesége lényegesen csökkenthető, ami jelentős mérvű költségcsökkenéssel jár.

A jóváhagyott első ütem szerint öszszesen 50 darab SPz Puma és GTK Boxer parancsnoki harcjárművet látnak el SVFuA-val. Emellett kiképzési célú 


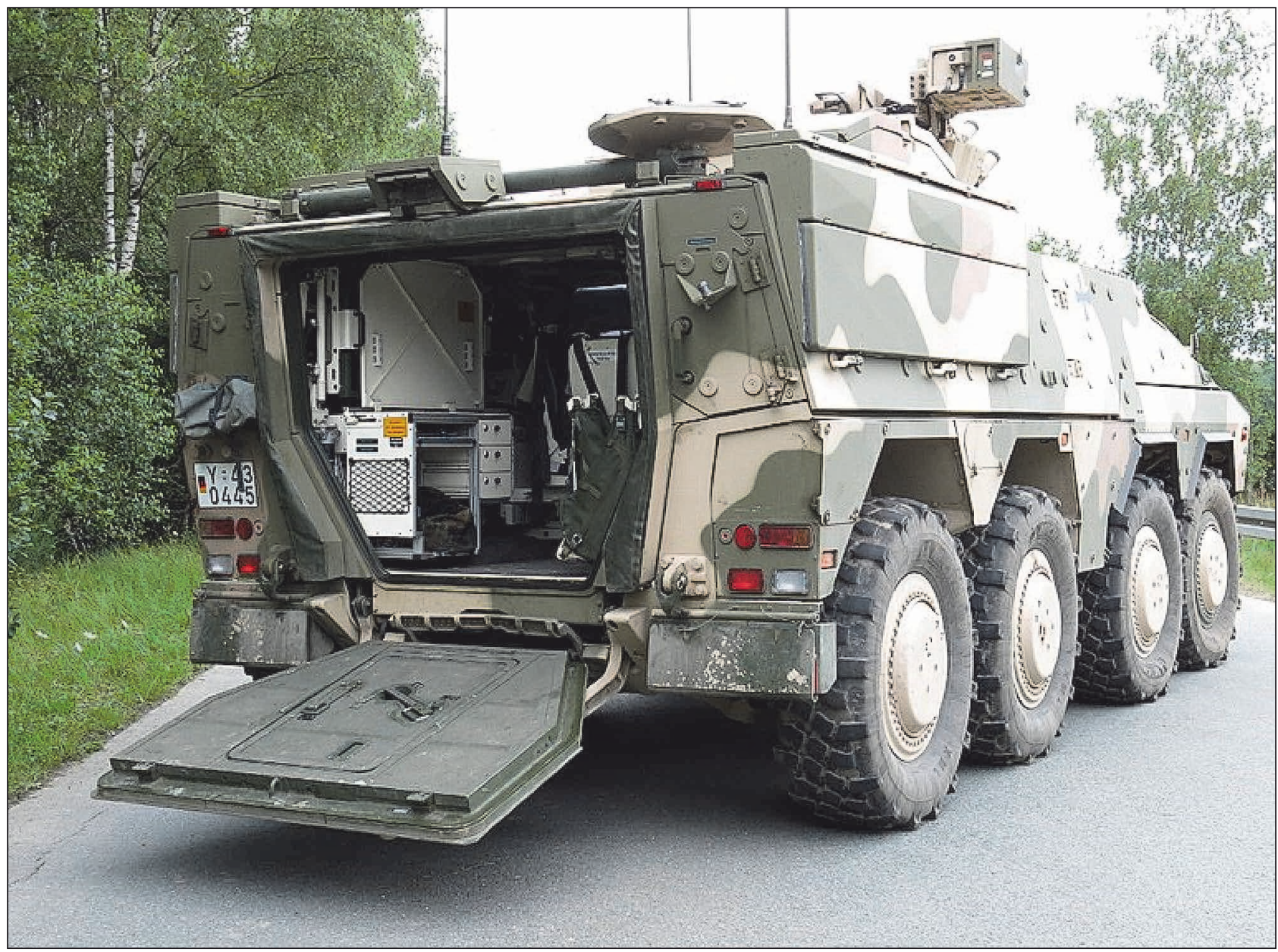

6. ábra. Parancsnoki GTK Boxer hátulnézeti képe, lenyitott hátsó rámpával

rádiókat kap a pöckingi vezetéstámogató iskola, az aacheni technikai kiképzőközpont, továbbá teszt- és referenciakészülékeket kap a grendingi haditechnikai intézet. A Bundeswehr haderőnemeinél az SVFuA komplett bevezetését a 2021-től tervezik.

A Bundeswehr harcászati rádiókommunikációs programja (MoTaKo) hosszú távú támogatása érdekében a Rohde \& Schwarz konszern közös vállalkozást hozott létre a Rheinmetall AG-val. Az új közös vállalatnál a Rheinmetall lesz felelős a teljes járműintegrációs folyamatért, több ezer jármű utólagos felszereléséért, a parancsrendszerekért, valamint a többfunkciós kezelőfelületekért, míg a Rohde \& Schwarz felel teljes körüen a védett beszéd- és adatátviteli rádiókommunikációs technológiákért, valamint az informatikai és internetes biztonságért. Mindkét német cég a megbízható technológiák széles portfoliójával és sokéves tapasztalattal rendelkezik a komplex haderőfejlesztési programok teljesítése terén.

\section{ForRÁsOK}

Taktische Kommunikation mit SVFuA: Rohde \& Schwarz stattet Bundeswehr mit modernen softwarebasierten Funksystemen aus. München: Rohde \&Schwarz, 2017. 07. 11.; https://www.rohde-schwarz.com/at/news-undpresse/pressebereich/pressemitteilungen-detailseiten/ taktische-kommunikation-mit-svfua-rohde-schwarzstattet-bundeswehr-mit-modernen-softwarebasierten- funksystemen-aus-pressemitteilungendetailseite_229356-452548.html [2018. 04. 16.];

Bundeswehr-journal SVFuA Archives. Bundeswehr Journal. www.bundeswehr-journal.de/tag/svfua/ [2018. 04.16.];

Taktische Bundeswehr-Kommunikation mit „SVFuA” In: Bundeswehr Journal. 2017. 07. 11. http://www. bundeswehr-journal.de/2017/taktische-bundeswehrkommunikation-mit-svfua/ [2018.04.16.];

Bundeswehr erhält SVFuA. Europäische Sicherheit \& Technik. 2017. 06. 28. www.esut.de/esut/archiv/ news-detail.../bundeswehr-erhaelt-svfua/ [2018. 04. 16.]; Digital Tactical Communications for German Army Command Vehicles: German Army Puma and Boxer command vehicles to be fitted with software-defined radio. Defence Procurement International, 2017. 07. 11. https://www.defenceprocurementinternational.com/ news/land/rohde-and-schwarz-radio-system-svfua [2018. 04. 17.];

Verträge für SVFuA und Aufklärungsdrohne unterzeichnet. hartpunkt.de, 2017. 07.11.;

https://www.hartpunkt.de/vertraege-fuer-svfua-undaufklaerungsdroh [2018. 04.17.];

Taktische Kommunikation mit SVFuA: Rohde \& Schwarz stattet Bundeswehr mit modernen softwarebasierten Funksystemen aus. griephan.de, 2017. 07. 11. https:// www.griephan.de/news/politik-wirtschaft/single-view/ news/taktische-kommunikation-mit-svfua-rohdeschwarz-stattet-bundeswehr-mit-modernensoftwarebasierten-funksystemen-aus.html [2018.04.17.]. 